\title{
Effects of Ankle Muscle Contraction Method on Strength, Flexibility and Balance of Ankle Joint in High School Soccer Player
}

\author{
Sang-hyup Song* \\ Seowon Universtiy, Cheongju, Korea
}

Received: December 15, 2017

Accepted: January 20, 2018

Published online: January 31, 2018

\section{Keywords:}

Ankle joint

Balance

Flexibility

Muscle contraction method

Strength
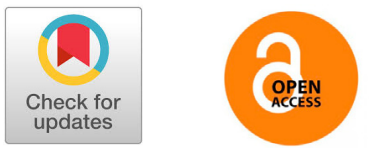

\section{ABSTRACT}

PURPOSE The purpose of this study was to investigate the effects of ankle muscle contraction method on strength, flexibility and balance of ankle joint in high school football player.

METHODS Thirty-six high school soccer male players participated in this study. There were three groups (1) concentric contraction exercise (CON, $n=12$ ), (2) eccentric contraction exercise ( $E C C, n=12)$ and (3) CON + ECC $(n=12)$. Exercise program consist of plantar flexion, dorsi flexion, and inversion, eversion and these exercise was performed 10 repetition, 2 set $(\mathrm{CON}+\mathrm{ECC}=1 \mathrm{set}), 30^{\circ} / \mathrm{sec}, 60^{\circ} / \mathrm{sec}, 90 \% \mathrm{sec}, 120^{\circ} / \mathrm{sec}$ in each group. All subjects performed same volume of exercise condition on a isokinetic exercise.

RESULTS First, the muscle strength of the ankle joint was significantly higher after isokinetic exercise program in plantar flexion $(p<.05)$, dorsi flexion $(p<.01)$, inversion $(p<, 05)$ and eversion $(p<.01)$. Second, the flexibility of the ankle joint was significantly higher than in plantar flexion ( $p<.01)$, dorsi flexion $(p<.05)$, inversion $(p<, 05)$ and eversion $(p<.01)$. Third, blance of the ankle joint was higher $(p<.05)$ in the anterior and anterolateral joints compared with the group that performed only the concentricl contraction and the eccentric contraction $(P<.05)$ compared to before the isokinetic exercise program. In the lateral direction, there was a significant difference between groups $(p<.01)$ and between measurement periods $(p<.05)$. In the posterolateral direction, the combination of the concentric contraction and eccentric contractions was higher than the group with only the concentric and eccentric contraction ( $P<.01)$. In the posterior direction, there was a significant difference between the groups $(p<.01)$ and the measurement period $(p<.05)$. Significant differences were noted between posteromedial and medial direction $(p<.01)$.

CONCLUSIONS These suggest that the combined of concentric and eccentric contraction exercise of ankle joint can improve to greater balance compared with only performing concentric and eccentric contraction exercise.

(c) The Asian Society of Kinesiology and the Korean Academy of Kinesiology

\section{서 론}

축구는 동적인 상황에서 패스, 킥, 태클, 터닝, 점핑과 같은 다양한 동작과 더불어 방향을 전환하며 이 때 발과 발목관절 주변의 근육들의 상호 복합적인 작용을 통하여 수행되는 스포츠 종목이다(Fong et al., 2007). 축구 경기에 서 가장 많이 발생하는 손상 부위는 발목이나 무릎과 같

*Correspondence: Sang-hyup Song, Seowon University, 377-3 Musimseoro, Heungdeok-gu, Cheongju, Chungbuk, Korea

E-mail adress: yo-hyup@hanmail.net
이 하지 관절부위에 빈번하게 나타나는 것으로 알려져 있 으며(Hawkins et al., 2001), 주로 발목의 염좌가 반복적으 로 나타나 만성적인 형태로 이어지고 있다.

만성적인 발목 염좌의 원인은 다양하지만 주로 앞정강 근(tibialis anterior muscle)과 긴종아리근(peroneus longus muscle)의 근력과 고유수용감각 기능의 감소로 인한 발목 의 불안정성이 증가하고, 결국 반복적인 발목 염좌를 일 으키는 요인이 된다(Kaminski \& Hartsell 2002; Lentell et al., 1995; Osborne et al., 2001). 또한, 반복적인 발목 염좌로 인 한 만성 통증과 발목의 기능 저하는 인대 손상 및 골절로 
인한 기계적 불안정성뿐만 아니라 연부 조직 손상 및 충 돌 증후군과 같은 원인적 질환들과 발목 관절의 유연성 감소와 같은 기능적 불안정성이 원인이 되고 있다(Rou \& Lee, 2012).

발목의 불안정성을 해결하기 위한 운동으로는 발목 주 위 근육강화 운동과 관절운동범위와 안정성을 위한 고유 수용성 감각 증진운동 그리고 민첩성 강화 운동을 포함 한 치료적 운동들이 요구되고 있다(Mattacola \& Mccluskey, 2001). 이러한 문제점들을 해결하기 위한 선행연구들 을 살펴보면 발목관절의 재 손상을 예방하기 위하여 뱁 스(BAPS: Biomechanical Ankle Platform System)보드와 같 이 도구를 이용한 방법(Noubuou et al., 2002; Osborne et al., 2001)과 기능적 발목관절 불안정시 앞정강근(Tibialis anterior)의 강화(Ebig et al., 1997), 만성외측인대 손상을 위 한 벌림근과 모음근의 운동감각 기능 향상(Lentell et al., 1995)으로 만성적인 발목 손상을 예방하고 치료하기 위해 노력하였다. 하지만 이처럼 발목 불안정성을 해결하기 위 한 다양한 운동과 치료방법에도 불구하고 발목 염좌는 반 복적으로 발생하고 있는 실정이다.

한편, 저항성운동의 근수축 특성은 등장성(isotonic)운 동이며, 등장성 운동은 다시 단축성수축(concentric contraction)과 신장성수축(eccentric contraction)으로 구분된 다. 운동으로 의한 근손상의 정도는 단축성 신장에 비해
신장성수축이 크다고 알려져 있지만(Kon et al., 2007), 신 장성수축의 특징은 근수축시 동원되는 운동단위가 적음 에도 불구하고 큰 장력 발휘가 가능하다고 알려져 있으 며(Ebbeling \& Clarkson, 1989; Enoka et al., 1992), 운동의 강 도를 동일하게 적용시킬 경우, 단축성 수축에 비해 근단 면적과 근력의 증가도 높은 것으로 보고되어 있다(Hortobagyi et al., 1996). 또한, 발목 관절의 동적 안정성은 지면 과 발목, 지면과 발의 충격력을 최소화하기 위해 근육의 상호수축 중 신장성수축과 단축성수축에 의해 일어나므 로(Zeevi \& Dvir, 1995). 발목관절에 신장성수축 운동을 적 용한다면 근력강화를 위한 트레이닝의 효과를 기대할 수 있을 것으로 생각된다.

이에 이 연구에서는 고등학교 축구선수를 대상으로 단 축성수축 $(\mathrm{CON})$ 과 신장성수축(ECC) 그리고 단축성과 신 장성수축 결합운동 $(\mathrm{CON}+\mathrm{ECC})$ 이 발목의 근력, 유연성 그리고 평형성에 미치는 영향을 알아보고자 한다.

\section{연구 방법}

\section{연구대상}

이 연구의 대상자는 경기도 소재 C재활센터에 내원한 고등학교 남자 축구선수 36 명을 대상으로 하였다. 이들은 지난 3 년간 오른발을 우세측으로 하는 발목에 3 회 이상 5

\begin{tabular}{|c|c|c|c|c|}
\hline Group & Age (yr) & Height $(\mathrm{cm})$ & Weight (kg) & $\mathrm{BMI}\left(\mathrm{kg} / \mathrm{m}^{2}\right)$ \\
\hline $\operatorname{CON}(n=12)$ & $18.3 \pm 0.7$ & $175.7 \pm 3.6$ & $69.4 \pm 6.6$ & $22.5 \pm 2.3$ \\
\hline $\operatorname{ECC}(n=12)$ & $18.7 \pm 1.0$ & $175.3 \pm 4.3$ & $71.9 \pm 5.2$ & $22.8 \pm 3.1$ \\
\hline $\mathrm{CON}+\mathrm{ECC}(\mathrm{n}=12)$ & $18.5 \pm 0.6$ & $174.3 \pm 5.8$ & $72.5 \pm 5.1$ & $23.4 \pm 1.9$ \\
\hline
\end{tabular}

\begin{tabular}{|c|c|c|c|c|c|}
\hline Group & Speed $(\% /$ sec $)$ & Repetition number & Set & Rest (sec) & Frequency (time/week) \\
\hline \multirow{4}{*}{ CON \& ECC } & 30 & 10 & \multirow{4}{*}{2} & \multirow{4}{*}{90} & \multirow{4}{*}{3} \\
\hline & 60 & 10 & & & \\
\hline & 90 & 10 & & & \\
\hline & 120 & 10 & & & \\
\hline \multirow{4}{*}{$\mathrm{CON}+\mathrm{ECC}$} & 30 & 10 & \multirow{4}{*}{1} & \multirow{4}{*}{90} & \multirow{4}{*}{3} \\
\hline & 60 & 10 & & & \\
\hline & 90 & 10 & & & \\
\hline & 120 & 10 & & & \\
\hline
\end{tabular}


회 미만의 만성 발목 염좌를 경험하였지만 최근 3 개월 이 내 발목 염좌가 없었으며 발목 이외의 신체는 의학적으로 이상이 없었다. 대상자는 본 실험의 취지에 대하여 충분 히 이해한 후에 참여하였다. 대상자들의 신체적 특성은 Table 1 과 같다.

\section{등속성 운동 프로그램}

대상자는 8주간 주3회 등속성 장비(Biodex system)를 이용하여 발목관절 운동 프로그램에 참여하였다. 준비운 동은 스트레칭과 고정식 자전거 에르고미터를 10 분간 실 시하였고, 본 운동으로 발목관절의 발바닥 굽힘(plantar flexion)과 발등 굽힘(dorsi flexion) 그리고 안쪽 번짐(inversion)과 가쪽 번짐(eversion)을 $30 \% \mathrm{sec}, 60 \% \mathrm{sec}, 90 \% \mathrm{sec}, 120 \%$ $\mathrm{sec}$ 에서 각 그룹의 특성에 맞는 근수축 방법을 10 회 2 세트 를 수행하였고, 단축성과 신장성수축이 결합된 그룹은 다 른 그룹과 운동량을 동일하게 하기 위하여 1세트를 수행 하였으며, 세트 간 휴식시간은 $90 \mathrm{sec}$ 로 하였다. 본 운동 이 후 정리운동으로 스트레칭과 자전거에르고미터를 실시 하였다. 등속성 운동 프로그램은 Hyun(2003)이 제시한 프 로그램을 수정 보완하여 Table 2에 제시하였다.

\section{발목관절의 유연성}

발목관절의 가동범위를 검사하기 위하여 고니오미터 를 사용하였으며 측정방법은 Norkin and White(2009)의 방법을 기초로 하여 측정하였다. 대상자는 의자에 앉아
발이 지면에 닿지 않은 상태에서 발목의 관절이 $90^{\circ}$ 도가 되도록 유지하였다.

(1) 발등 굽힘/발바닥 굽힘

측정자는 대상자의 발목이 중립상태를 유지한 상태에 서 발목이 발등 굽힘과 발바닥 굽힘이 되도록 손을 이용 하여 가볍게 유도하였으며, 이때 측정자의 추가적인 자 극이 전달되지 않도록 최소한의 힘으로 측정을 실시하였 다. 고니오미터의 축은 발목관절의 안쪽에 움직이지 않도 록 고정하고 고정팔은 하퇴의 안쪽면의 중심을 따라 위치 하였으며, 운동팔은 첫 번째 중족골을 따라 위치한 후 측 정하였다.

(2) 안쪽 번짐/가쪽 번짐

측정자는 대상자의 발목이 중립상태를 유지한 상태에 서 경골과 비골을 움직이지 않도록 고정한 후 발목을 안 쪽 번짐과 가쪽 번짐을 측정하였다. 안쪽 번짐은 측정자 가 저측 굴곡과 안쪽 번짐동작을 유도하여 측정하였으며, 가쪽 번짐은 측정자가 가쪽 번짐과 발등 굽힘 동작을 유 도한 후측정하였다.

\section{등속성 근력}

발목관절의 등속성 근력 측정을 위해 Biodex system III(New York, USA)를 이용하였다. 검사 전 대상자가 익숙 하게 적응할 때까지 준비운동으로 충분히 실시하였다. 대 상자는 측정기기에 등을 뒤로 편안하게 기대어 앉았다.

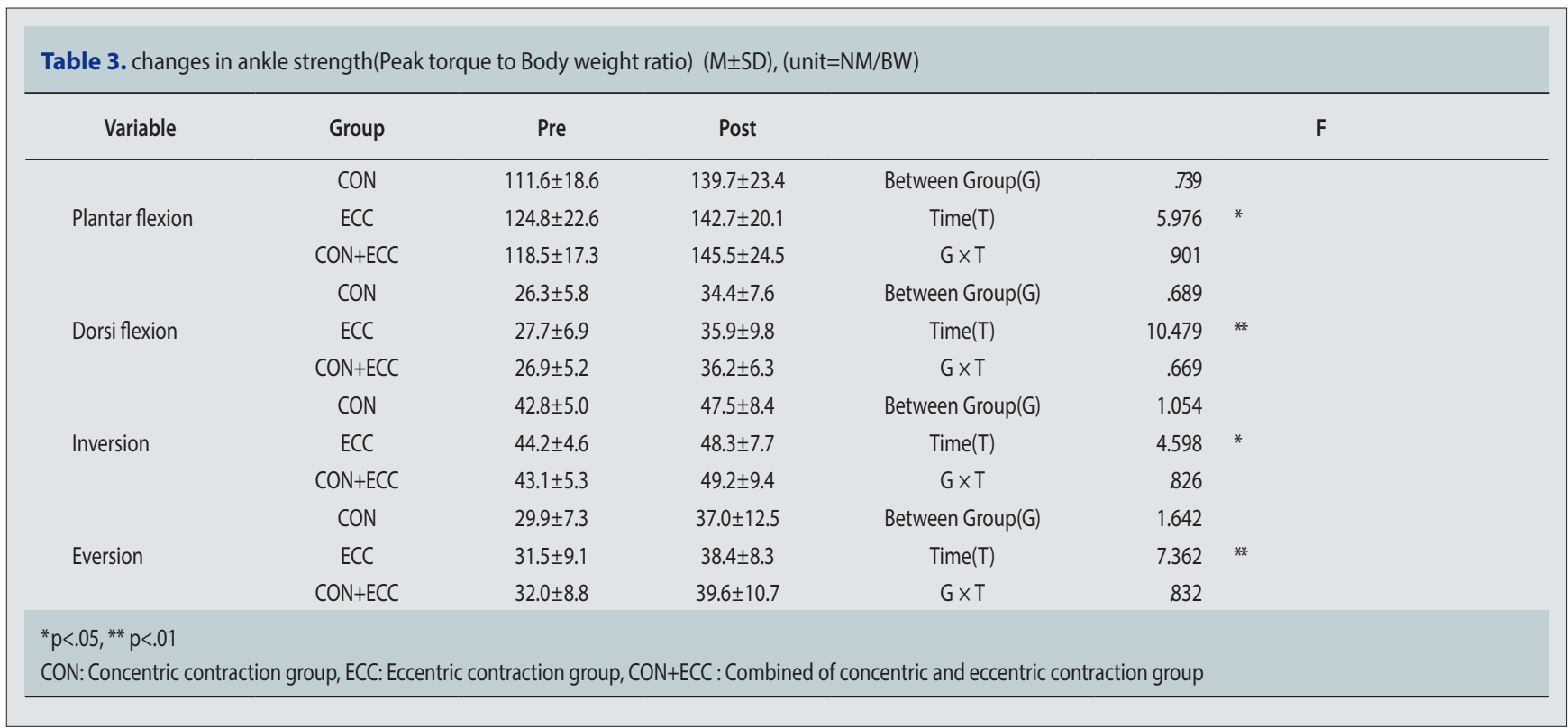




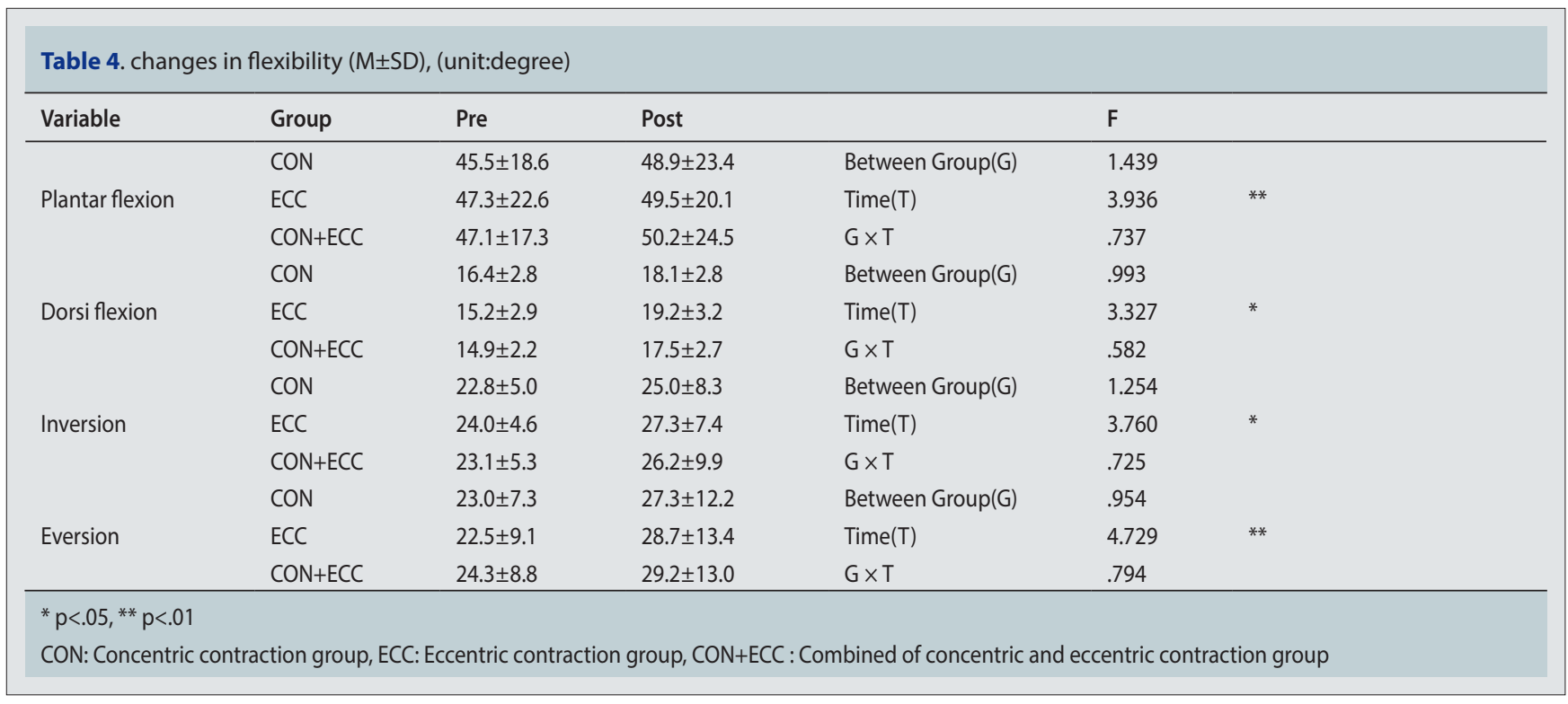

발목관절의 운동축과 기계의 운동축이 일치하도록 위치 시킨 상태에서 발목관절 이외의 관절의 움직임을 최소화 하기 위하여 상태와 골반 그리고 하지를 고정하였다. 발 목관절의 운동범위는 대상자의 안전을 고려하여 안쪽 번 짐 $0^{\circ}-55^{\circ}$, 가쪽 번짐 $0^{\circ}-40^{\circ}$, 발바닥 굽힘 $0^{\circ}-50^{\circ}$, 발등 굽힘 $0^{\circ}-20^{\circ}$ 로 제한하여 측정하였으며, 측정 전 3 회의 연습을 수행하고 각속도 $60 \% \mathrm{sec}$ 로 5 회 실시 하였으며 검사 간 휴 식시간은 30 초를 주었다.

\section{평형성 검사}

발목의 평형성 검사는 축구선수의 특성을 고려하여 동 적 평형성 검사 Star Excursion Balance Test(SEBT)를 실시 하였다. SEBT 검사는 편평한 바닥에 앞쪽(anterior), 앞가 쪽(anterolateral), 가쪽(lateral), 뒤가쪽(posterolateral), 뒤쪽 (posterior), 뒤안쪽(posteromedial), 안쪽(medial), 앞안쪽 (anteromedial)의 전.후.좌·우.대각 방향의 8 개의 선 위에서 실시하는 검사로 한다리(오른발)로 가운데에 중심을 잡 고 서서 반대 측 다리(왼발)를 이용하여 최대한 멀리 뻗는 기능적 검사방법이다. 이때 중심선에서 최대로 뻗은 지점 까지의 거리 $(\mathrm{cm})$ 를 측정하여 기록하였으며, 검사자간 오 차를 줄이기 위하여 동일한 검사자에 의하여 측정되었다.

\section{자료처리}

이 연구의 자료는 SPSS(Ver 20.0) 통계프로그램을 이용 하여 측정 항목의 평균과 표준편차를 분석하였다. 운동
집단(3)×측정시기(2)에 따른 운동 프로그램에 효과를 검 증하기 위하여 repeated measured two-way ANOVA를 실시 하였다. 유의한 차이가 있는 변인의 사후검증(post hoc)은 Tukey 방법을 실시하였으며, 통계학적 유의수준은 $\alpha<.05$ 로 하였다.

\section{결 과}

\section{발목관절의 근력}

발목관절의 근력은 Table 3에 제시한 바와 같다. 운동 프로그램 전.후 발목관절의 근력은 발바닥 굽힘근, 발등 굽힘근, 안쪽 번짐, 가쪽 번짐 모두 그룹 간 유의한 차이 는 나타나지 않았고, 측정 시기 간에는 발바닥 굽힘근 $(\mathrm{p}<.05)$, 발등 굽힘근 $(\mathrm{p}<.01)$, 안쪽 번짐 $(\mathrm{p}<.05)$, 가쪽 번짐 $(\mathrm{p}<.01)$ 에서 유의한 차이가 나타났으며, 그룹 간 상호작용 효과는 통계적으로 유의한 차이가 없었다.

\section{발목관절의 유연성}

발목관절의 유연성은 Table 4 에 제시한 바와 같다. 운동 프로그램 전.후 발목관절의 유연성은 발바닥 굽힘근, 발 등 굽힘근, 안쪽 번짐, 가쪽 번짐 모두 그룹 간 유의한 차 이는 나타나지 않았고, 측정 시기 간에는 발바닥 굽힘근 $(\mathrm{p}<.01)$, 발등 굽힘근 $(\mathrm{p}<.05)$, 안쪽 번짐 $(\mathrm{p}<.05)$, 가쪽 번짐 $(\mathrm{p}<.01)$ 에서 유의한 차이가 나타났으며, 그룹 간 상호작용 효과는 통계적으로 유의한 차이가 없었다. 


\begin{tabular}{|c|c|c|c|c|c|c|c|}
\hline Variable & Group & Pre & Post & & $F$ & & Post hoc \\
\hline & CON & $72.2 \pm 8.6$ & $74.5 \pm 5.4$ & Between Group(G) & 3.739 & * & \\
\hline \multirow[t]{3}{*}{ Anterior } & ECC & $71.4 \pm 5.6$ & $73.7 \pm 7.9$ & Time(T) & 5.976 & * & $A, B<C$ \\
\hline & $\mathrm{CON}+\mathrm{ECC}$ & $72.5 \pm 7.3$ & $79.2 \pm 5.2$ & $G \times T$ & 3.901 & * & \\
\hline & CON & $74.3 \pm 5.8$ & $75.4 \pm 7.6$ & Between Group(G) & 4.689 & * & \\
\hline \multirow[t]{3}{*}{ Anterolateral } & ECC & $73.7 \pm 6.9$ & $74.9 \pm 9.8$ & Time(T) & 5.479 & * & $A, B<C$ \\
\hline & $\mathrm{CON}+\mathrm{ECC}$ & $72.9 \pm 5.2$ & $81.8 \pm 6.3$ & $G \times T$ & 4.669 & * & \\
\hline & CON & $79.6 \pm 5.0$ & $82.5 \pm 8.4$ & Between Group(G) & 12.355 & $* *$ & \\
\hline \multirow[t]{3}{*}{ Lateral } & ECC & $81.3 \pm 4.6$ & $85.3 \pm 7.7$ & Time(T) & 4.598 & * & $A<B<C$ \\
\hline & $\mathrm{CON}+\mathrm{ECC}$ & $80.7 \pm 5.3$ & $97.2 \pm 9.4$ & $\mathrm{G} \times \mathrm{T}$ & 3.826 & & \\
\hline & $\mathrm{CON}$ & $86.7 \pm 6.2$ & $88.8 \pm 5.3$ & Between Group(G) & 11.423 & $* *$ & \\
\hline \multirow[t]{3}{*}{ Posterolateral } & ECC & $87.3 \pm 6.9$ & $89.6 \pm 7.5$ & Time(T) & 3.536 & * & $A, B<C$ \\
\hline & $\mathrm{CON}+\mathrm{ECC}$ & $88.3 \pm 7.7$ & $97.6 \pm 8.7$ & $G \times T$ & 3.746 & & \\
\hline & CON & $82.7 \pm 7.0$ & $83.3 \pm 7.2$ & Between Group(G) & 12.355 & $* *$ & \\
\hline \multirow[t]{3}{*}{ Posterior } & ECC & $85.3 \pm 5.5$ & $88.9 \pm 6.4$ & Time(T) & 3.344 & * & $A<B<C$ \\
\hline & $\mathrm{CON}+\mathrm{ECC}$ & $84.8 \pm 7.4$ & $100.4 \pm 7.0$ & $G \times T$ & 5.932 & $* *$ & \\
\hline & CON & $78.6 \pm 7.6$ & $82.5 \pm 6.2$ & Between Group(G) & 2.355 & & \\
\hline \multirow[t]{3}{*}{ Posteromedial } & ECC & $79.9 \pm 6.3$ & $83.2 \pm 7.8$ & Time(T) & 4.637 & * & ns \\
\hline & $\mathrm{CON}+\mathrm{ECC}$ & $77.3 \pm 8.9$ & $86.5 \pm 7.3$ & $G \times T$ & .632 & & \\
\hline & $\mathrm{CON}$ & $68.3 \pm 6.0$ & $71.6 \pm 6.2$ & Between Group(G) & 1.355 & & \\
\hline \multirow[t]{3}{*}{ Medial } & ECC & $70.9 \pm 6.3$ & $73.5 \pm 6.4$ & Time(T) & 3.367 & * & ns \\
\hline & $\mathrm{CON}+\mathrm{ECC}$ & $68.3 \pm 7.5$ & $75.3 \pm 7.3$ & $G \times T$ & .533 & & \\
\hline & CON & $61.8 \pm 6.6$ & $62.4 \pm 6.2$ & Between Group(G) & 1.355 & & \\
\hline \multirow[t]{2}{*}{ Anteromedial } & ECC & $62.4 \pm 7.0$ & $63.5 \pm 8.4$ & Time(T) & 1.576 & & ns \\
\hline & $\mathrm{CON}+\mathrm{ECC}$ & $62.8 \pm 6.8$ & $65.1 \pm 12.3$ & $\mathrm{G} \times \mathrm{T}$ & .436 & & \\
\hline \multicolumn{8}{|c|}{$\begin{array}{l}\text { CON: Concentric contraction group, ECC: } E \\
A: C O N, B: E C C, C: C O N+E C C\end{array}$} \\
\hline
\end{tabular}

\section{발목관절의 평형성}

발목관절의 평형성은 Table 5에 제시한 바와 같다. 운동 프로그램 전.후 발목관절의 평형성은 앞쪽과 앞가쪽 방향 에서 그룹 간( $\mathrm{p}<.05)$, 측정 시기 간 $(\mathrm{p}<.05)$ 에 유의한 차이가 나타났으며, 상호작용 효과도 통계적으로 유의한 차이가 있었다 $(\mathrm{p}<.05)$. 가쪽 방향에서는 그룹 간 $(\mathrm{p}<.01)$, 측정 시 기 간 $(\mathrm{p}<.05)$ 에 유의한 차이가 나타났으나 상호작용 효과 는 통계적으로 유의하지 않았다. 뒤가쪽 방향에서는 그 룹 간 $(\mathrm{p}<.01)$, 측정 시기 간 $(\mathrm{p}<.01)$ 에 유의한 차이가 나타 났으나 상호작용 효과는 없었다. 뒤쪽(posterior) 방향에 서는 그룹 간 $(\mathrm{p}<.01)$, 측정 시기 간 $(\mathrm{p}<.05)$ 에 유의한 차이 가 나타났으며, 상호작용 효과도 통계적으로 유의한 차이 를 보였다(p<.01). 뒤안쪽과 안쪽 방향에서는 그룹 간 유 의한 차이는 나타나지 않았으나 시기 간 $(\mathrm{p}<.01)$ 에 유의한 차이가 나타났다. 앞안쪽 방향에서는 그룹 간, 측정 시기 간에 통계적으로 유의한 차이가 없었다.

\section{논 의}

만성 발목관절 염좌는 고유수용감각의 이상으로 근력 을 감소시켜 발목관절의 불안정성을 초래하며, 특히 축구 선수들의 반복적인 점프 동작과 방향 전환 등과 같은 기 능적 동작 수행 시 발목관절에 과도한 부하를 주어 반복 적으로 발목손상을 재발시켜 결과적으로 경기력 향상에 문제를 일으킨다. 이러한 문제를 예방하고 회복하기 위 해서 발목관절 주위의 근육 강화를 포함한 여러 가지 재 활 훈련 프로그램 등이 제시되고 있다(Balogun et al., 1992; Tropp et al., 1994). Del and Thomas(2005)는 단축성수축 운 동 시 운동단위 발현 비율은 신장성수축 운동보다 높은 것으로 나타나며, 일부 저강도의 운동에서 유사한 비율 을 보인다고 하였다. 이러한 이유는 신장성수축 운동 동 안의 전반적인 근육의 장력이 높기 때문이다. 일반적으로 신장성수축의 근력은 단축성수축의 근력보다 $120 \%$ 높음 
에도 불구하고 최대근력발현 시 전체 운동단위를 동원하 지 않는다고 하였다(Tesch et al., 1990). 또한, 신장성수축 운동은 근육의 적응, 근력 발현 능력 그리고 근비대의 측 면에서 단축성수축과 비교하여 우수한 것으로 알려져 있 다. 하지만 이러한 선행 연구와 달리 이 연구의 결과 단축 성수축 그룹, 신장성수축 그룹, 그리고 단축성수축과 신 장성수축을 결합한 그룹 모두 발목관절의 발바닥쪽 굽힘 근, 발등 굽힘근, 안쪽 번짐, 가쪽 번짐에서 발목관절의 근 력이 향상된 것으로 나타났다. 즉, 단축성수축과 신장성 수축의 근수축 유형과 관계없이 근력을 향상시킨 것으로 보인다. 이러한 이유는 단축성수축과 신장성수축의 반복 적인 운동이 발목 관절 주변의 근육을 강화시켰으며 운동 단위의 점증(recruitment)과 발화율(fire rate)의 증가와 더 불어 운동강도에 따른 근섬유의 비율 중 type $\Pi \mathrm{b}$ 의 단위 가 증가한 것으로 생각된다.

유연성은 관절 주위에 존재하는 근육 결합조직의 신장 성 기능이 증가하여, 근력뿐만 아니라 운동 수행력도 증 가한다. 관절의 가동범위 $(\mathrm{ROM})$ 는 유연성, 근력, 순발력 이외에도 협응성에 영향을 주며(Hrysomallis, 2011) 발목 이 정상적인 기능을 유지하려면 먼저 관절의 가동범위가 정상적인 수준으로 회복되어야 한다(John, 2000). 이 연구 의 결과 유연성은 단축성수축 그룹, 신장성수축 그룹, 그 리고 단축성수축과 신장성수축을 결합한 그룹 모두 등속 성 운동 프로그램 전과 비교하여 발목관절의 발바닥 굽 힘근, 발등 굽힘근, 안쪽 번짐, 가쪽 번짐에서 발목관절의 유연성이 향상된 것으로 나타났으나 그룹의 차이는 나타 나지 않았다. Karlsson(1998)은 근력과 협응력 운동을 통 해 관절의 유연성을 확보함으로서 인대 손상환자의 약 80 90\%가 정상적인 발목 기능으로 회복되었다고 보고하 였다. 또한 발목 관절의 유연성이 낮을 수 록 점프 수행 력(Alpkaya \& Koceja, 2007)과 균형 능력이 감소된다(Lee, 2005)는 선행연구들이 있지만 유연성은 근육이 정상적인 위치로 되돌아오는 탄력성과 반복적인 손상으로 인한 가 소성의 의미에서 다양한 해석이 가능할 것으로 생각된다. 비록 유연성이 향상 되었다 하더라도 주변근육의 근력 보 강이 이루어지지 않는다면 약화된 근력으로 인해 오히려 손상의 원인으로 작용할 수 있을 것이라 생각된다. 이러 한 측면에서 이 연구에서 수행하였던 근력의 강화를 기 반으로 한 기능적 평형성 능력의 개선이 선행되었다고 생 각한다.

인체의 평형을 유지하기 위해서는 가장 먼저 발목, 대
퇴, 상체 그 다음으로 몸을 전체적으로 조절하여 중심을 잡는다(Horak \& Nashner, 1986). 이 연구의 결과 앞쪽, 앞 가쪽, 가쪽, 뒤가쪽, 뒤쪽에서 단축성수축과 신장성수축 을 결합한 그룹에서 평형성이 향상된 것으로 나타났으며, 측정 시기에 따라서는 앞안쪽을 제외한 모든 요인에서 유 의한 차이가 있는 것으로 나타났다. 이러한 방향에서 동 원되는 근육은 발목의 앞정강근과 관련된 동작이었으며 앞정강근은 발목의 외전력에 관여하고 있다. 즉, 발목관 절의 외전력 보강이 발목관절의 안정성을 유지하기 위한 주된 요인으로 생각된다. 이러한 결과는 만성적 발목 염 좌 환자의 발목 외전력의 차이가 안정성에 중요한 역할을 하지만 명백한 발목 관절의 외전력 차이가 없다면 근력강 화운동이 필요하지 않다(Kaminski et al., 1999; Lentell et al., 1995)는 연구와 만성적 발목 불안정성이 있는 대상자에 게 단축성 근력과 신장성 근력을 측정한 결과 안쪽 번짐 및 가쪽 번짐의 근력 모두가 건강한 사람들과 비교하여 유의 하게 낮았다(Hartsell \& Spauding, 1999)고 보고한 연구와 같은 의견을 제시하고 있다. 또한, 자세를 유지하기 위해 서는 체성감각, 시각, 전정계 정보를 토대로 중추에서 수 합 명령하여 근육을 통해 나타내는 반응으로 설명할 수 있다. 이 연구에서 수행된 신장성수축은 근육의 길이를 감지하여 뇌에 신호를 보낸 이후에 단축성수축을 통하여 근육의 길이 조절을 한다. 이는 신경계가 신전-단축주기 (stretch-shortening cycle)에 보다 빠르게 반응하기 위해 적 응되는 과정으로(Johnson et al., 2011) 신경근계의 반응 능 력을 개선시켜 신경 계의 흥분을 증가시키는 것이다. 이러 한 과정을 통하여 단축성수축과 신장성수축을 결합한 그 룹에서 보다 좋은 평형성 결과를 보인다고 생각된다. 특 히 근육의 사전 활성기(preactivation)가 나타나는 시점을 단축시키고 구심성 신경에서 시작된 자극을 운동신경의 원심성 신경을 거쳐 효과기인 근육에 도달시키는 근육 반 사궁 (reflex arc) 반응 시간을 단축시켜(Kim et al., 2012) 평 형성 유지에 긍정적인 영향을 미치는 것으로 생각한다.

인체는 움직임을 수행할 때 자세와 운동조절을 하기 위하여 대뇌 단독으로 수행하는 것이 아니라 말초신경계 와 근육, 척수, 뇌간, 소뇌, 및 대뇌 등이 어떤 체계를 이루 어 행해지는 것으로 알려져 있으며(Gurfinkel et al., 1988), 특히 인체가 평형성을 유지하기 위해서는 특정 근육만이 동원되는 것이 아니라 외부자극에 대해 근육과 신경의 협 력반응이 조화를 이루는 것이 평형성 유지에 중요하다 (Macpherson, 1991). 아울러 하지의 기계적 불안정성과 발 
목 이외의 관절들의 상호작용과 같은 요인에 대하여 상세 히 살펴볼 필요가 있다.

이 연구에서는 단축성수축과 신장성수축 운동을 통한 근력과 유연성의 결과에 기초한 평형성에 대한 연구를 수 행하였으나 신장성수축과 평형성과의 명확한 기전과 상 관관계를 반영하지는 못하였지만 축구선수의 반복적인 발목관절 손상의 관리 측면에서 의미 있는 기초자료를 제 공할 수 있으리라 생각된다. 향후 추가적인 연구를 통하 여 재발 가능성과 형태학적 변화를 보완할 필요성은 제 기되었다.

\section{결 론}

고등학교 축선선수들의 발목 관절의 재활 운동 프로그 램을 위해서는 단축성수축과 신장성수축 그리고 단축성 수축과 신장성수축을 겹합한 등속성운동을 통하여 근력 과 유연성에는 차이가 없었지만 기능적인 평형성 능력에 는 단축성수축과 신장성수축을 결합한 운동이 더욱 효과 가 있었다는 것을 알 수 있었다. 따라서 발목 염좌로 인한 불안정성 운동 프로그램에는 근력, 유연성과 더불어 평 형성의 체력 요소를 강화하기 위해서 단축성수축과 신장 성수축 운동이 필요하다고 생각된다.

\section{Conflicts of Interest}

The authors declare no conflict of interest.

\section{References}

Alpkaya, U., \& Koceja, D. (2007) The effects of acute static stretching of reaction time and force. The Journal of Sports Medicine and Physical Fitness, 47(2), 147-150.

Balogun, J. A., Adesinasi, C. O., \& Marzouk, D. K. (1992). The effect of a wobble board exercise training program on static balance performance and strength of lower extremity muscle. Physiology Therapy Canadian, 44, 23-29.

Del Valle A, \& Thomas Ck. (2005). Fifing rates of motor units during strong dynamic contractions. Muscle Nerve, 32, 316-325.

Ebbeling C. B., \& Clarkson, P. M. (1989). Exercise-induced muscle damage and adaptation. Sports Medicine. 7, 207-234.

Ebig, M., Lephart, S. M., \& Burdett, R. G. (1997). The effect of sudden inversion stress on EMG activity of the peroneal and tibialis anterior muscles in the chronically unstable ankle. Journal of Orthopedic Sports Physical Therapy, 26, 73-77.

Enoka, R. M. (1992). Eccentric contractions require activation strategies by the nervous system. Journal of Applied Physiology. 81, 1339-2346.

Fong, D. T., Hong, Y., Chan, L. K., Yung, P. S., \& Chan, K. M. (2007). A systematic review on ankle injury and ankle sprain in sports. Sports Medicine, 37(1), 73-94.

Gurfinkel, V. S., Lipshits, M. I., \& Lestienne, F. G. (1988). Anticipatory neck muscle activity associated with rapid arm movements. Neurosci Lett. 94, 104-108.

Hartsell, H. D., \& Spaulding, S. J. (1999). Eccentric/concentric ratios at selected velocities for the invertor and evertor muscles of the chronically unstable ankle. British Journal of Sports Medicine, 33, 255-258.

Hawkins, R. D., Hulse, M. A., \& Wilkinson, C. (2001). The association football medical research program: An audit of injuries in professional football. British Journal of Sports Medicine. 35, 43-47.

Horak, F. B., \& Nashner, L. M. (1986). Central programming of postural movements : adaptation to altered support-surface configurations. Journal of Neurophysiology. 55(6), 1369-1381.

Hortobagyi, T., Hill, J. P., \& Israel, R. G. (1996). Adaptive responses to muscle lengthening and shortening in humans. Journal of Applied Physiology. 80: 765-772.

Hrysomallis, C. (2011). Blance ability and athletic performance. Sports Medicine. 41(3), 221-232.

Hyun, G. S. (2003). The Effects of Isokinetic Exercise Programs on the Muscular Function Recovery of Athletes with Chronic Ankle Sprain. Journal of Sport and Leisure Studies, 19(2), 1503-1513

John, C. (2000). Treatment of achilles tendon ruptures. The Journal of Orthopaedic Surgery, 8(1), 97-99.

Johnson, B. A., Salzberg, C. L., \& Stevenson, D. A. (2011). A sysytematic rewiew: plyometric training programs ofr young children. Journal of Strength \& Conditioning Research, 29(9), 2623-2633.

Kaminski, T. W., Perrin, K. H., \& Gansneder, B. M.(1999). Eversion Strength Analysis of Uninjured and Functionally Unstable Ankles. Journal of Athletic Training, 34(3), 239-245. 
Kaminski, T. W., \& Hartsell, H. D. (2002). Factors contributing to chronic ankle instability: A strength perspective. Journal of Athletic Training, 37(4), 394-405.

Karlsson, J. (1998). Ligament injuries of the ankle. Lakartidningen, 95(40), 4376-4378.

Kim, Y. M., Kim, T. S., Jee, Y. S., Yoon, J. H., (2012). Effects of 12-weeks Plyometric Training on Motor Nerve Conduction Velocity and Knee Isokinetic Muscular Functions in Boys while Attending Community-based Soccer Club. Journal of Sports and Leisure, 49, 981-990.

Kon, M., Tanabe, K., Lee, H., Kimura, F., Akimoto, T., \& Kono, I. (2007). Eccentric muscle contractions induce greater oxidative stress than concentric contractions in skeletal muscles. Applied Physiology, Mutrition, and Metabolism. 32, 273-282.

Lee, S. E. (2005). Effects of Increasing Ankle Range of Motion Program on Ambulation and Balance for the Elderly with Balance Disorder. Korean Research Society of Physical Therapy, 12(2), 28-36.

Lentell, G. L., Bass, B., Lopez., D., McGuire, L., Sarrels, M., \& Snyder, P. (1995). The contribution of proprioceptive deficits, muscle function, and anatomical laxity to functional instability of the ankle. Journal of Orthopedic and Sports Physical Therapy, 21, 206-215.

Macpherson, J. M. (1991). How flexible are muscle synergies? In : Motor control : Concepts and Issues, (pp. 33-47), New York : Wiley.
Mattacola, C. G., \& Mccluskey, L. C. (2001). Management of ankle sprains. Americans Family Physician. 63(1), 93-104.

Nobuou, Matsusaka, Shigeki, Yokoyama, Toshiya, Shigeru, Inokuchi, Peter, Vaes, William, Duquet, \& Bart, van Gheluwe. (2002). Peroneal reaction time and eversion motor response in healthy and unstable ankles. Journal of Athletic Training. $37(4), 475-480$.

Norkin, C. C., \& White, D. J. (2009). Measurement of Joint Motion: A Guide to Goniometry. F a Davis.

Osbborne, M. D., Chou, L. S., Laskowski, E. R., Smith, J., \& Kaufman, K. R. (2001). The Effects of Ankle Disk Training on Muscle Reaction Time in Subjects with a History of Ankle Sprain. American Journal of Sports Medicine, 29(5), 627-632.

Tesch, P. A., Dudley, G. A., Duvoisin, M. R., Hather, B. M., \& Harris, R. T. (1990). Force and EMG signal patterns during repeated bouts of concentric or eccentric muscle actions. Acta Physiologica Scandinavica. 138, 263-271.

Rou, S. K., Lee, C. H. (2012). Effects of the presence of disease on the ankle joint in isokinetic muscular of hip joint. The korea journal of sports science, 21(2), 1239-1248.

Tropp, H., Askling, C., \& Gillquist, J. (1994). Prevention of ankle sprains. The American Journal of Sports Medicine, 13(4), 259-262.

Zeevi \& Dvir. (1995). isokinetics; Muscle Testing, Interpretation and Clinical Applications. Churchill Livingstone. 